\title{
Effect of the antioxidant type phytonutrients diet supplementation on lamb quality
}

\author{
Desislava Vlahova-Vangelova ${ }^{1}$, Nikolay Kolev ${ }^{1 *}$, Dessislav Balev ${ }^{1}$, Nevyana Stancheva, Jivko Nakev ${ }^{2}$, \\ and Stefan Dragoev ${ }^{1,3}$

\footnotetext{
${ }^{1}$ Department of Meat and Fish Technology, Technological Faculty, University of Food Technologies, Plovdiv, Bulgaria

${ }^{2}$ Department of Animal Science, Agricultural Institute, Agricultural Academy, Shumen, Bulgaria

${ }^{3}$ Assembly of Academicians and Corresponding Members, Bulgarian Academy of Science, Sofia, Bulgaria
}

\begin{abstract}
The aim of the study was to estimate the effect of Siberian larch dihydroquercetin and dry distilled rose petals supplementation of lambs' diet on the quality of meat obtained from Bulgarian dairy synthetic population sheep. The experiments were performed with 30 clinically healthy male lambs aged 65 days with equal live weight. There were studied one control group $(\mathrm{C})$ fed for 50 days with ground alfalfa + granulated compound feed and two experimental groups (D) and (R) fed on the same diet supplemented either with 7.5 $\mathrm{mg}$ dihydroquercetin/ $\mathrm{kg} /$ day or with $545 \mathrm{mg}$ DDRP/kg/day respectively. The DDRP diet supplementation increases the sensory scores, carotenoids and essential amino acids of muscles $(\mathrm{P} \leq 0.05)$ but does not affect the content of tocopherols. No significant differences $(\mathrm{P}>0.05)$ were found comparing the proximate composition of the group C, $\mathrm{R}$ and D. Compared to control group $\mathrm{C}$ the supplementation of lambs' diet with dihydroquercetin and DDRP contributes to a certain increase in the sterols in muscle and adipose tissues but not in liver tissue $(\mathrm{P} \leq 0.05)$. A reduction of $\mathrm{WHC}$ of $\mathrm{m}$. Longissimus dorsi and microbial deterioration in both muscles and perirenal fatty tissue was found in experimental groups D and R.
\end{abstract}

\section{Introduction}

Nowadays various approaches to modifying the proximate composition and improving the quality and nutritional value of meat are increasingly being discussed [1-4]. The addition of various natural antioxidants to diets in order to increase the oxidative stability of meat has also been suggested [5].

Various plant extracts and preparations with antioxidant and bactericidal properties have been widely studied including: tea catechins and $\alpha$-tocopherol [6], ethanol extracts of rosemary, white peony, red peony, sapan wood [7], anise, dill, black pepper, cinnamon [8] etc. Relatively newer, beneficial to human health, biologically active ingredients such as dihydroquercetin from Siberian larch (Larix sibirica Ledeb) [9] and dry distilled rose petals (Rosa damascena Mill.) (DDRP) [10] have also been studied.

Two main bioflavonoids have been found in the bark of Siberian larch: dihydroquercetin and dihydrokaempferol [11]. Dihydroquercetin is an electron donor which is due to its effect for inhibiting hydroxyl radicals [12]. It inactivates alkyl peroxyl and superoxide radicals [13], reduces phospholipase C-induced hemolysis and inhibits superoxide produced by xanthine oxidase [14].

\footnotetext{
*Corresponding author: nik0zzz11@gmail.com
}

The antihemolytic effect of dihydroquercetin is probably not directly mediated by the removal of free radicals but is due to its interaction with the cell

membrane. It is used in preventing of oxidative stress [15] and has a therapeutic effect on cancer, cardiovascular and liver diseases [15]. An interesting by-product from the production of rose oil and rose water is DDRP. It contains a wide range of antioxidant components with a synergistic effect [17].

The aim of the study was to estimate the effect of Siberian larch dihydroquercetin and dry distilled rose petals supplementation of lambs' diet on the quality of meat obtained from Bulgarian dairy synthetic population sheep.

\section{Materials and Methods}

\subsection{Experimental design of lambs' breeding and fattening}

The experiments were performed with 30 clinically healthy male lambs aged 65 days with equal live weight in the Experimental Base of the Agricultural Institute, Shumen (section of the Agricultural Academy, Sofia, Bulgaria). One control group (C) fed for 50 days with ground alfalfa + granulated compound feed and two experimental groups (D) and (R) fed on the same diet supplemented either with $7.5 \mathrm{mg}$ dihydroquercetin $/ \mathrm{kg} /$ day 
or with $545 \mathrm{mg}$ DDRP $/ \mathrm{kg} /$ day, respectively, were studied [10]. The amounts of the two phytonutrients added to the feed are commensurate with the live weight of the animals.

The experiment started when weaning lambs with an average live weight of $15 \mathrm{~kg}$ and continued until reaching $28 \mathrm{~kg}$. Feeding was free with free access to water. Feed consumption was monitored daily and lamb weight development was monitored every 15 days. After reaching the determined live weight the lambs from the three groups were slaughtered (Fig. 1).
Factory (Lyuben Karavelovo village, municipality of Aksakovo, district of Varna, Bulgaria). The amount of compound feed and its consumption during the experiment were monitored daily. Residual feed was weighed and subtracted from the daily feed intake. The lambs were weighed every two weeks.

Dihydroquercetin is provided by the company Flavitlife Bio JSCo (Sofia) and DDRP were supplied by the rose oil distillery of Bulattars Production Company Ltd (Pavel Banya, district Stara Zagora, Bulgaria). After pressing the petals were dried $\left(24 \mathrm{~h}\right.$, at $\left.65^{\circ} \mathrm{C}\right)$ and ground

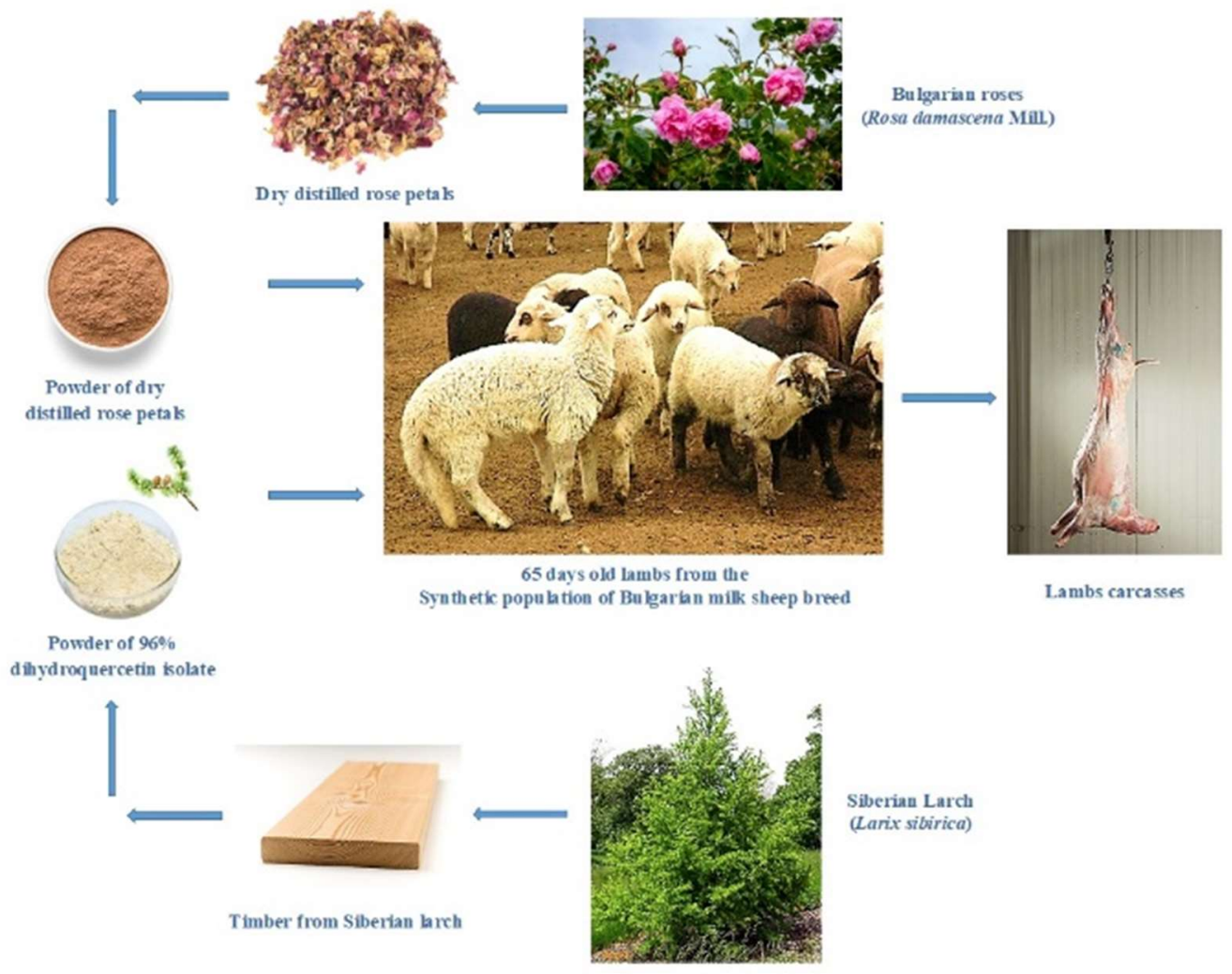

Fig. 1. Experimental design of breeding and fattening lambs from the Synthetic population of Bulgarian dairy sheep.

This experiment was conducted in accordance with Art. 14 of Part V. Breeding and livestock units of the European Convention for the protection of vertebrate animals used for experimental and other scientific purposes, Council Directive 2010/63/EC, Commission Recommendation 2007/526/EC and Council Regulation (EC) №1099/2009 as well as the national legislation of the Republic of Bulgaria (Law on Veterinary Medicine and Ordinance № 20 of 1 November 2012). The lambs were fed ad libitum in group feeders with access to water and salt. Individual daily doses of the supplements were calculated according to the previous weighting of the animals, mixed with additional feed [10] and given with the morning feeding.

\subsection{Feed and phytonutrients}

The ground alfalfa + the additional granulated compound feed for lambs were delivered by the Vasil Kostov Feed to a particle size $<0.4 \mathrm{~mm}$. The daily dose of additives was calculated according to the previous dose, mixed with feed mixture [10] and given to the lambs with the morning meal.

\subsection{Methods}

\subsubsection{Sensory analysis}

The sensory analysis was performed in a sensory laboratory according to the ISO 8589: 1988 [18] at 20 $23^{\circ} \mathrm{C}$. The two deboned muscles were tasted raw and cooked after cooking in an electric oven wrapped in foil. The cooking was stopped when the temperature of the center of the samples $72^{\circ} \mathrm{C}$ has been reached and a holding of $10 \mathrm{~min}$ has been made. Each sample was cut into nine parts and was served on preheated plates to a panel of nine trained panellists. Water and bread were used as neutralizers. The assessors used a hedonic five ball scale for the evaluation. The panellists evaluated smell, taste, texture, color and appearance [19]. 


\subsubsection{Proximate composition analysis}

The samples taken from the $\mathrm{m}$. Longissimus lumborum et thoracis hereinafter referred to as $\mathrm{m}$. Longissimus dorsi and $\mathrm{m}$. Semimembranosus (weighing between $90-100 \mathrm{~g}$ ) were analyzed for contents of dry matter, protein, intramuscular fat and ash.

The content of dry matter was determined in homogenized meat samples of $10 \mathrm{~g}$ dried at $105^{\circ} \mathrm{C}$ for $5 \mathrm{~h}$ [20]. The protein content was calculated as the content of nitrogen multiplied by 6.25 by the Kjeldahl method [21] using an automatic nitrogen analyzer model UDK 152. The content of intramuscular fat was determined by the method of Bligh and Dyer [22]. The ash content was determined by burning in a laboratory furnace at $550^{\circ} \mathrm{C}$ by a standard method [21].

\subsubsection{Determination of sterols}

The lipids of meat were isolated by hydrolysing the sample with hydrochloric acid and the fat released was extracted by petroleum ether recovered and calculated as a percentage of the weight of the original sample [23].

The content of sterols was determined on HP 5890 gas chromatograph equipped with $25 \mathrm{~m} \times 0.25 \mathrm{~mm}$ DB -5 capillary column and flame ionization detector. Temperature gradient from $90^{\circ} \mathrm{C}$ (hold $3 \mathrm{~min}$ ) up to $290^{\circ} \mathrm{C}$ at a rate of change $15^{\circ} \mathrm{C} / \mathrm{min}$ and then up to $310^{\circ} \mathrm{C}$ at a rate of $4^{\circ} \mathrm{C} / \mathrm{min}$ (hold $10 \mathrm{~min}$ ); detector temperature $-320^{\circ} \mathrm{C}$; injector temperature $-300^{\circ} \mathrm{C}$ the carrier gas being hydrogen. Identification was confirmed by comparison of retention times with those of a standard mixture of sterols [24].

\subsubsection{Determination of tocopherols}

Tocopherols were determined directly in the lipids by HPLC analysis on a Merck-Hitachi (Merck, Darmstadt, Germany) instrument equipped with $250 \mathrm{~mm} \times 4 \mathrm{~mm}$ Nucleosil Si 50-5 column and fluorescent detector MerckHitachi F 1000 [25]. The operating conditions were mobile phase of n-hexane: dioxane, 96:4 (v/v) and flow rate $1 \mathrm{~mL} / \mathrm{min}$, excitation $295 \mathrm{~nm}$, emission $330 \mathrm{~nm} .20$ $\mu \mathrm{L} 1 \%$ solution of crude oil in $\mathrm{n}$-hexane were injected. Tocopherols were identified by comparing the retention times with those of authentic individual ones.

\subsubsection{Determination of carotenoids}

One $\mathrm{g}$ of the fat was dissolved in $20 \mathrm{ml}$ of hexane and total carotenoids were measured spectrophotometrically at 452 $\mathrm{nm}$. The content of carotenoids was taken from the obtained ratio [26]. Total carotenoids were calculated by equation (1):

$$
\mathrm{C}=\mathrm{E} \lambda 1 . \mathrm{V} \cdot 100: 250 . \mathrm{G} . \mathrm{CB}
$$

where:

$\mathrm{V}$ - volume of the diluted extract, $\mathrm{cm}^{3}$;

$\mathrm{G}$ - mass of the sample taken for analysis, g;

CB - dry matter of the sample taken for analysis, $\%$

\subsubsection{Amino acid analysis}

Studies on the amino acid composition of muscle proteins were performed by high performance liquid chromatography [27] on an HPLC gradient liquid chromatographic system Thermo Scientific, model Finnigan Surveyor.

\subsubsection{Determination of WHC}

The water holding capacity of meat (WHC) was determined according to the amount of free water by the method of Grau and Hamm [28].

\subsubsection{Microbiological analysis}

The microbiological analysis of the samples was made by bacteriological tests [29] carried out in accordance with Regulation (EC) № 1441 of 05.12.2007.

\subsubsection{Statistical analysis}

The statistical analysis was processed by software packages Microsoft Excel 5.0 and SAS Release 9.1 for Windows [30]. The two-way ANOVA was made using Student t-test $(\mathrm{p}<0.05)$.

\section{Results and Discussion}

\subsection{Sensory characteristics}

The results from the sensory analysis of $\mathrm{m}$. Longissimus dorsi showed that the highest sensory scores were obtained from samples R followed by samples D and the lowest being in control samples C (Fig. 2 and Fig. 3).

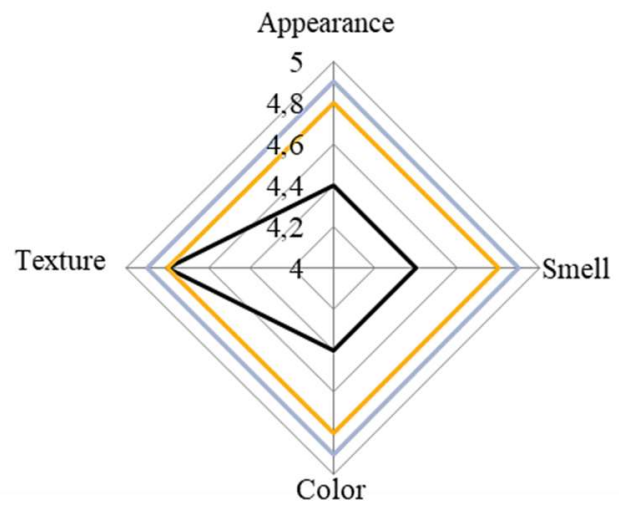

C L.dorsi

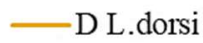

- R L.dorsi

Fig. 2. Sensory characteristics of the raw $\mathrm{m}$. Longissimus dorsi.

Similar results were reported for samples of $\mathrm{m}$. Semimembranosus (Fig. 4 and Fig. 5). They demonstrated higher sensory scores in samples R obtained from lambs consumed feed with the addition of DDRP and samples D (dihydroquercetin) compared to control samples C. 


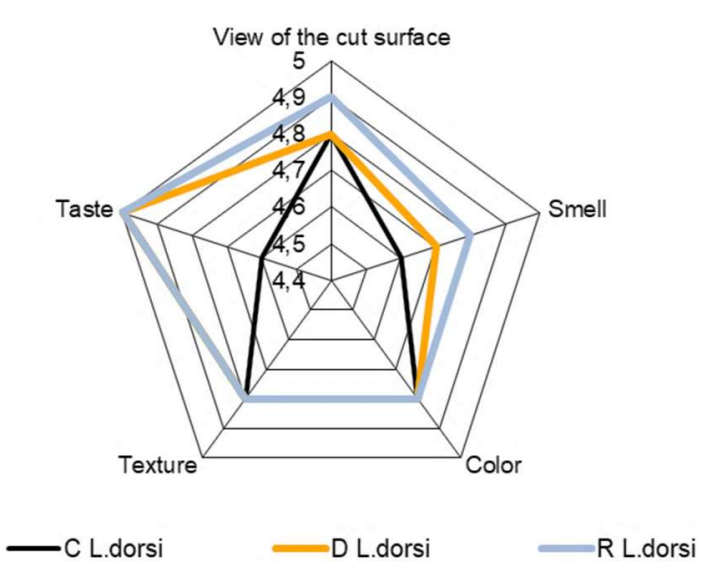

Fig. 3. Sensory characteristics of the cooked m. Longissimus dorsi.

The conclusion was made that the diet supplementation of lambs from the Synthetic population Bulgarian dairy sheep with $7.5 \mathrm{mg}$ dihydroquercetin $/ \mathrm{kg} / \mathrm{d}$ and especially with $545 \mathrm{mg} \mathrm{DDRP} / \mathrm{kg} / \mathrm{d}$ leads to a significant improvement in the sensory quality of the meat and can successfully be used as an approach in this direction.

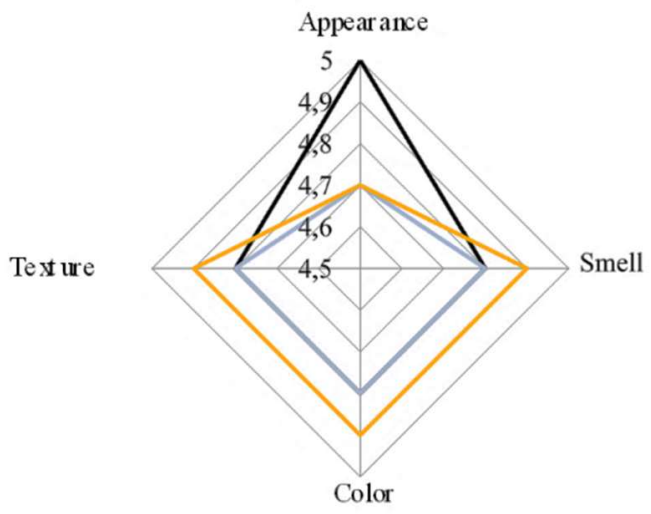

C Semimem.

-D Semimem.

R Semimem.

Fig. 4. Sensory characteristics of the raw $\mathrm{m}$. Semimembranosus.

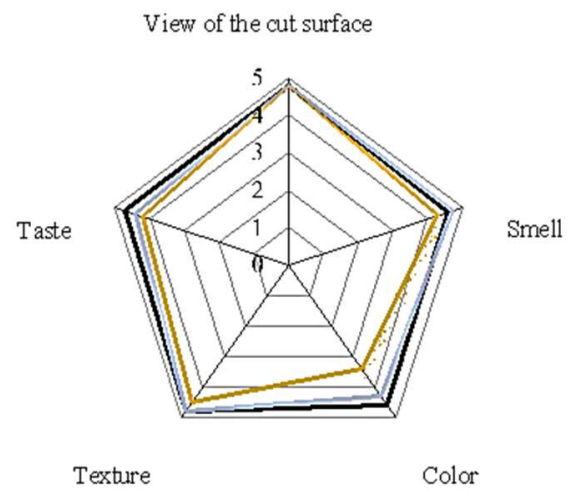

C m. Semimem. $\quad$ D m. Semimem.

R m. Sem imem.

Fig. 5. Sensory characteristics of the cooked m. Semimembranosus.

\subsection{Proximate composition}

No significant differences $(\mathrm{P}>0.05)$ were found comparing the proximate composition of the group $\mathrm{C}, \mathrm{R}$ and $\mathrm{D}$ in $\mathrm{m}$. Longissimus dorsi and $\mathrm{m}$. Semimembranosus respectively (Fig. 6).

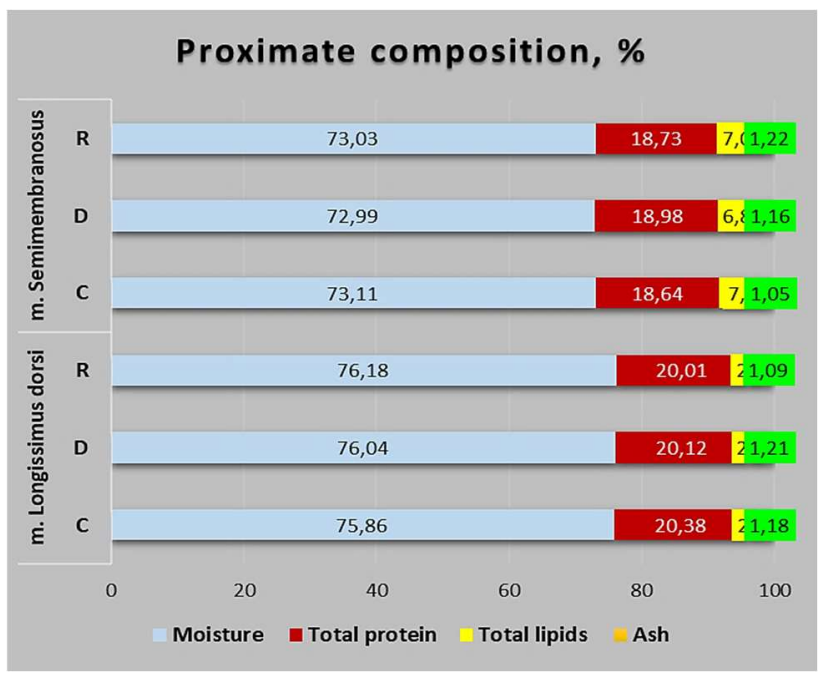

Fig. 6. Proximate composition of the lambs' $m$. Longissimus dorsi and $\mathrm{m}$. Semimembranosus from three studied samples.

\subsection{Sterols, tocopherols and carotenoids}

Only traces of tocopherols were found in muscle $(\mathrm{m}$. Longissimus dorsi) and perirenal adipose tissue as well as in the liver lipids (Table 1).

In contrast, the content of carotenoids and sterols in the liver lipids exceeds many times than the one found in muscle (m. Longissimus dorsi) lipids and in the perirenal adipose tissue (Table 1). Compared to control group C, the supplementation of lambs' diet with dihydroquercetin and DDRP contributes to a certain increase in the sterols in muscle and adipose tissues but not in liver tissue $(\mathrm{P} \leq$ 0.05).

Comparisons by tissue type show that the highest concentrations of carotenoids were found in samples R. In contrast, the sterol content was the highest in samples D of $\mathrm{m}$. Longissimus dorsi and in control samples $\mathrm{C}$ - from liver tissue whereas in perirenal adipose tissue it is negligibly low - in the range of $0.03-0.09 \%$ (Table 1 ). The results thus established are evidence that supplementation of lambs' feed with $545 \mathrm{mg}$ DDRP $/ \mathrm{kg} / \mathrm{d}$ stimulates the accumulation of carotenoids in the liver and to a lesser extent in adipose and muscle tissue while supplementation of lambs' feed with $7.5 \mathrm{mg}$ dihydroquercetin $/ \mathrm{kg} / \mathrm{d}$ stimulates almost twice as high accumulation of sterols in $\mathrm{m}$. Longissimus dorsi but significantly reduces their levels in the liver.

\subsection{Amino acid composition}

The supplementation of the combined fodder for fattening lambs from the Synthetic population of Bulgarian dairy sheep with the two studied phytonutrients has a significant effect on the amino acid composition of the lambs' 
samples (Table 2). These results show that the approach used to introduce biologically active polyphenolic ingredients into the body of lambs through food can be successfully applied in order

Table 1. Content of sterols, tocopherols and carotenoids in muscle tissue (m. Longissimus dorsi), perirenal adipose tissue and liver of lambs fed with the addition of phytonutrients, $1 \mathrm{~d}$ post mortem.

\begin{tabular}{|l|c|c|c|c|c|c|c|c|c|}
\hline Samples & \multicolumn{2}{|c|}{ m. Longissimus dorsi } & \multicolumn{2}{c|}{ Perirenal adipose tissue } & \multicolumn{4}{c|}{ Liver } \\
\hline Parameter & $\mathbf{C}$ & $\mathbf{D}$ & $\mathbf{R}$ & $\mathbf{C}$ & $\mathbf{D}$ & $\mathbf{R}$ & $\mathbf{C}$ & $\mathbf{D}$ & $\mathbf{R}$ \\
\hline Sterols, \% & $\begin{array}{c}0.77 \\
\pm 0.19^{c}\end{array}$ & $\begin{array}{c}1.56 \\
\pm 0.09^{e}\end{array}$ & $\begin{array}{c}1.15 \\
\pm 0.16^{d}\end{array}$ & $\begin{array}{c}0.03 \\
\pm 0.01^{a}\end{array}$ & $\begin{array}{c}0.07 \\
\pm 0.01^{b}\end{array}$ & $\begin{array}{c}0.09 \\
\pm 0.02^{b}\end{array}$ & $\begin{array}{c}5.41 \\
\pm 0.28^{h}\end{array}$ & $\begin{array}{c}3.10 \\
\pm 0.17^{f}\end{array}$ & $\begin{array}{c}4.02 \\
\pm 0.20^{g}\end{array}$ \\
\hline Tocopherols, $\mathrm{mg} / \mathrm{kg}$ & traces & traces & traces & traces & traces & traces & traces & traces & traces \\
\hline Carotenoids, $\mathrm{mg} / \mathrm{kg}$ & $\begin{array}{c}4.10 \\
\pm 0.22^{c}\end{array}$ & $\begin{array}{c}4.50 \\
\pm 0.25^{c d}\end{array}$ & $\begin{array}{c}4.90 \\
\pm 0.23^{d}\end{array}$ & $\begin{array}{c}1.40 \\
\pm 0.12^{a}\end{array}$ & $\begin{array}{c}3.30 \\
\pm 0.07^{b}\end{array}$ & $\begin{array}{c}4.70 \\
\pm 0.11^{d}\end{array}$ & $\begin{array}{c}10.20 \\
\pm 0.15^{e}\end{array}$ & $\begin{array}{c}19.40 \\
\pm 0.23^{f}\end{array}$ & $\begin{array}{c}24.80 \\
\pm 0.38^{g}\end{array}$ \\
\hline
\end{tabular}

* The results are presented as Mean \pm SEM.

The different indices $(\mathrm{a}, \mathrm{b}, \mathrm{c}, \mathrm{d}, \mathrm{e}, \mathrm{f}, \mathrm{g}, \mathrm{h}$, and i) in the same order show the presence of statistically significant differences $(\mathrm{p} \leq 0.05)$

Table 2. Amino acid composition of lamb $\mathrm{m}$. Longissimus dorsi and $\mathrm{m}$. Semimembranosus affected by feed supplementation with phytonutrients after 1 day storage at $0-4^{\circ} \mathrm{C}$.

\begin{tabular}{|c|c|c|c|c|c|c|}
\hline \multirow{2}{*}{$\begin{array}{r}\text { Lamb muscles } \\
\text { Amino acids, g/100 g protein }\end{array}$} & \multicolumn{3}{|c|}{ m. Longissimus dorsi } & \multicolumn{3}{|c|}{ m. Semimembranosus } \\
\hline & $\mathbf{C}$ & D & $\mathbf{R}$ & $\mathrm{C}$ & D & $\mathbf{R}$ \\
\hline Valine & $4.82 \pm 0.05^{\mathrm{a}}$ & $5.32 \pm 0.03^{b}$ & $4.85 \pm 0.07^{\mathrm{a}}$ & $4.81 \pm 0.05^{\mathrm{a}}$ & $4.89 \pm 0.04^{\mathrm{a}}$ & $4.84 \pm 0.07^{a}$ \\
\hline Leucine & $8.10 \pm 0.02^{b}$ & $8.57 \pm 0.05^{c}$ & $9.10 \pm 0.02^{d}$ & $7.03 \pm 0.02^{\mathrm{a}}$ & $8.02 \pm 0.05^{b}$ & $8.59 \pm 0.04^{\mathrm{c}}$ \\
\hline Isoleucine & $4.29 \pm 0.08^{b}$ & $4.84 \pm 0.12^{\mathrm{d}}$ & $5.29 \pm 0.05^{\mathrm{e}}$ & $3.19 \pm 0.07^{\mathrm{a}}$ & $4.64 \pm 0.02^{c}$ & $5.34 \pm 0.10^{\mathrm{e}}$ \\
\hline Lysine & $8.93 \pm 0.15^{b}$ & $9.43 \pm 0.11^{\mathrm{d}}$ & $10.23 \pm 0.09^{\mathrm{f}}$ & $8.77 \pm 0.05^{\mathrm{a}}$ & $9.03 \pm 0.08^{\mathrm{c}}$ & $9.67 \pm 0.10^{\mathrm{e}}$ \\
\hline Methionine & $2.60 \pm 0.03^{b}$ & $3.09 \pm 0.02^{\mathrm{d}}$ & $2.29 \pm 0.10^{\mathrm{a}}$ & $2.76 \pm 0.05^{\mathrm{c}}$ & $3.93 \pm 0.02^{\mathrm{f}}$ & $3.21 \pm 0.07^{\mathrm{e}}$ \\
\hline Cysteine & $1.36 \pm 0.05^{\mathrm{d}}$ & $1.95 \pm 0.02 \mathrm{e}$ & $1.13 \pm 0.06^{\mathrm{c}}$ & $0.47 \pm 0.02^{\mathrm{a}}$ & $0.77 \pm 0.03^{b}$ & $0.77 \pm 0.02^{b}$ \\
\hline Threonine & $5.04 \pm 0.12^{\mathrm{c}}$ & $4.99 \pm 0.03^{c}$ & $5.30 \pm 0.07^{\mathrm{d}}$ & $4.04 \pm 0.04^{\mathrm{a}}$ & $5.57 \pm 0.06^{\mathrm{e}}$ & $4.47 \pm 0.05^{b}$ \\
\hline Tryptophan & $1.51 \pm 0.04^{\mathrm{a}}$ & $1.73 \pm 0.02^{b}$ & $1.59 \pm 0.05^{\mathrm{a}}$ & $1.49 \pm 0.03^{\mathrm{a}}$ & $1.50 \pm 0.04^{\mathrm{a}}$ & $1.51 \pm 0.02^{\mathrm{a}}$ \\
\hline Phenylalanine & $3.50 \pm 0.08^{\mathrm{a}}$ & $4.83 \pm 0.10^{c}$ & $4.80 \pm 0.09^{\mathrm{c}}$ & $3.54 \pm 0.05^{b}$ & $5.10 \pm 0.07^{d}$ & $6.34 \pm 0.11^{\mathrm{e}}$ \\
\hline Tyrosine & $4.03 \pm 0.10^{b}$ & $4.90 \pm 0.15^{c}$ & $4.91 \pm 0.11^{\mathrm{c}}$ & $3.70 \pm 0.04^{\mathrm{a}}$ & $5.34 \pm 0.02^{d}$ & $6.36 \pm 0.10^{\mathrm{e}}$ \\
\hline Essential amino acids & $44.18 \pm 0.11^{b}$ & $49.56 \pm 0.09 d$ & $49.49 \pm 0.13^{d}$ & $39.80 \pm 0.06^{a}$ & $48.79 \pm 0.05^{\mathrm{c}}$ & $51.10 \pm 0.10^{\mathrm{e}}$ \\
\hline Alanine & $6.68 \pm 0.15^{b}$ & $6.04 \pm 0.12^{\mathrm{a}}$ & $6.66 \pm 0.13^{b}$ & $8.16 \pm 0.11^{\mathrm{d}}$ & $8.12 \pm 0.07^{\mathrm{d}}$ & $7.68 \pm 0.09^{c}$ \\
\hline Aspartic acid & $6.26 \pm 0.05$ & $5.41 \pm 0.07^{\mathrm{a}}$ & $5.74 \pm 0.05$ & $7.68 \pm 0.07$ & $7.89 \pm 0.05$ & $7.38 \pm 0.04$ \\
\hline Glutamic acid & $14.80 \pm 0.03^{\mathrm{e}}$ & $12.29 \pm 0.02^{\mathrm{a}}$ & $12.78 \pm 0.08^{c}$ & $16.56 \pm 0.02^{b}$ & $12.41 \pm 0.04^{b}$ & $13.75 \pm 0.07^{d}$ \\
\hline Histidine & $3.61 \pm 0.15^{b}$ & $3.90 \pm 0.09^{c}$ & $3.83 \pm 0.15^{b c}$ & $5.29 \pm 0.10^{d}$ & $3.62 \pm 0.13^{b}$ & $3.06 \pm 0.07^{\mathrm{a}}$ \\
\hline Serine & $3.38 \pm 0.10^{\mathrm{a}}$ & $3.60 \pm 0.13^{b}$ & $3.34 \pm 0.07^{\mathrm{a}}$ & $4.03 \pm 0.05^{\mathrm{d}}$ & $3.92 \pm 0.04^{\mathrm{c}}$ & $3.43 \pm 0.05^{\mathrm{a}}$ \\
\hline Glycine & $8.52 \pm 0.02^{f}$ & $8.02 \pm 0.08^{\mathrm{e}}$ & $7.25 \pm 0.02^{d}$ & $6.37 \pm 0.02^{\mathrm{c}}$ & $5.88 \pm 0.05^{b}$ & $4.40 \pm 0.10^{a}$ \\
\hline Proline & $5.28 \pm 0.05^{\mathrm{e}}$ & $4.57 \pm 0.03^{c}$ & $4.85 \pm 0.09^{d}$ & $5.73 \pm 0.07^{\mathrm{f}}$ & $4.18 \pm 0.05^{b}$ & $3.62 \pm 0.10^{a}$ \\
\hline Arginine & $7.29 \pm 0.10^{f}$ & $6.61 \pm 0.03^{\mathrm{e}}$ & $6.06 \pm 0.11^{\mathrm{c}}$ & $6.38 \pm 0.04^{\mathrm{d}}$ & $5.19 \pm 0.05^{\mathrm{a}}$ & $5.58 \pm 0.11^{b}$ \\
\hline Replaceable amino acids & $55.82 \pm 0.12^{d}$ & $50.44 \pm 0.08^{b}$ & $50.51 \pm 0.11^{b}$ & $60.20 \pm 0.099^{e}$ & $51.21 \pm 0.06^{c}$ & $48.90 \pm 0.08^{a}$ \\
\hline
\end{tabular}

* The results are presented as Mean \pm SEM.

The different indices $(\mathrm{a}, \mathrm{b}, \mathrm{c}, \mathrm{d}, \mathrm{e}, \mathrm{f}, \mathrm{g}, \mathrm{h}$, and i) in the same order show the presence of statistically significant differences (p $\leq 0.05)$

A significant increase in essential amino acids has been found. In the samples from $\mathrm{m}$. Longissimus dorsi this increase is more than $5 \%$ for both feed additives in the samples of $\mathrm{m}$. Semimembranosus. The largest increase in essential amino acids was recorded in samples obtained from lambs receiving feed with the addition of $545 \mathrm{mg} \mathrm{DDRP} / \mathrm{kg} / \mathrm{d}$ - more than $11 \%$ while in samples obtained from lambs receiving feed with the addition of $7.5 \mathrm{mg}$ dihydroquercetin $/ \mathrm{kg} / \mathrm{d}$ it was about $9 \%$. to increase the quality and nutritional value of the protein fraction of lamb.

\subsection{Water holding capacity}

It was found (Table 3) that the addition of $7.5 \mathrm{mg}$ dihydroquercetin $/ \mathrm{kg} / \mathrm{d}$ or $545 \mathrm{mg} \mathrm{DDRP} / \mathrm{kg} / \mathrm{d}$ to the lambs' feed leads to a significant decrease of the water holding capacity of lamb - by approx. $0.3 \%$ at $\mathrm{m}$. Longissimus dorsi and by about $1 \%$ at $\mathrm{m}$. Semimembranosus. Those results well correspond with 
the changes in the sample's $\mathrm{pH}$. It is well known that as the $\mathrm{pH}$ value of the muscles approaches the isoelectric point of the myofibrillar protein myoglobin the WHA of the meat decreases and the amount of individual muscle juice increases.

\subsection{Microbiological status}

A reduction of microbial deterioration in both muscles and perirenal adipose tissues was found in experimental groups $\mathrm{D}$ and $\mathrm{R}$.

Table 3. Water holding capacity of lambs $\mathrm{m}$. Longissimus dorsi and $\mathrm{m}$. Semimembranosus affected by feed supplementation with phytonutrients after one day of storage at $0-4^{\circ} \mathrm{C}$

\begin{tabular}{|l|c|c|c|c|c|c|}
\hline Lamb muscles & \multicolumn{3}{|c|}{ m. Longissimus dorsi } & \multicolumn{3}{c|}{ m. Semimembranosus } \\
\hline Parameter & C & D & R & C & D & R \\
\hline WHC, \% & $98.51 \pm 0.13^{\mathrm{c}}$ & $98.21 \pm 0.07^{\mathrm{b}}$ & $98.25 \pm 0.08^{\mathrm{b}}$ & $98.74 \pm 0.12^{\mathrm{c}}$ & $97.81 \pm 0.15^{\mathrm{a}}$ & $97.66 \pm 0.11^{\mathrm{a}}$ \\
\hline
\end{tabular}

* The results are presented as Mean \pm SEM.

The different indices (a, b, c, d, e, f, g, h, and i) in the same order show the presence of statistically significant differences ( $\leq \leq 0.05)$.

\section{Conclusions}

The results showed that supplementation of lambs' feed with $7.5 \mathrm{mg}$ dihydroquercetin $/ \mathrm{kg} / \mathrm{d}$ or $545 \mathrm{mg}$ DDRP $/ \mathrm{kg} / \mathrm{d}$ did not affect significantly the proximate composition and tocopherol content of $\mathrm{m}$. Longissimus dorsi and $\mathrm{m}$. Semimembranosus. The DDRP supplementation contributes to the development of more acceptable sensory properties of lamb.

Both supplementations of lambs' feed with $7.5 \mathrm{mg}$ dihydroquercetin $/ \mathrm{kg} / \mathrm{d}$ or $545 \mathrm{mg}$ DDRP $/ \mathrm{kg} / \mathrm{d}$ increased the levels of the essential amino acids and to a little extent decreased the water holding capacity of $\mathrm{m}$. Longissimus dorsi and $\mathrm{m}$. Semimembranosus and reduced the microbial deterioration in muscle and perirenal adipose tissues.

The dihydroquercetin supplementation of lambs' diet contributes to a certain increase in the sterols in muscle and adipose tissues but not in liver tissue and DDRP supplementation of lambs' diet affects the content of carotenoids.

Finally, a future research for a more highly supplemented dose of dihydroquercetin, DDRP or their combination is recommended.

Acknowledgements: This work was supported by the Bulgarian National Science Fund (BNSF), Ministry of Education and Science of Republic of Bulgaria of state contract No DN 06/8 of 17 December 2016 "Study of the mechanism of biological active compounds of plant origin accumulation in the organism of Bulgarian breed agricultural animals and their impact on the meat quality as a natural functional food".

\section{References}

1. G. Nieto, P. Díaz, S. Bañón, M.D. Garrido, Meat Sci. 84, 23 (2010)

2. Z. Nasir, M.A. Grashorn, J. Anim. Feed Sci. 19, 93 (2010)

3. L., Yan, J.P. Wang, H.J. Kim, Q.W. Meng, X. Ao, S.M. Hong, I.H. Kim, Livestok Sci. 128, 115 (2010)

4. S.R. Hashemi, H. Davoodi, J. Anim. Veter. Adv. 9, 2295 (2010)
5. A.B. Falowo, P.O. Fayemi, V. Muchenje, Food Res. Int. 64, 171 (2014)

6. S. Tang, J.P. Kerry, D. Sheehan, D.J. Buckley, P.A. Morrissey, Food Res. Int. 34, 651 (2001)

7. J. Han, K.S. Rhee, Meat Sci. 70, 25 (2005)

8. S. Dwivedi, M.N. Vasavada, D.J. Cornforth, Food Sci. 71, C12 (2006)

9. L. Vladimirova-Kitova, ...To the modern aspect of athéroscléroses (VAP, Plovdiv, 2011)

10. N.Z. Stancheva, J.L. Nakev, D.B. VlahovaVangelova, D.K. Balev, S.G. Dragoev, Ir. J. Appl. Anim. Sci. 11, 339 (2021)

11. Y. Kolesnik, E. Titova, V. Chertkov, V. Tashlitsky, V. Tikhonov, D. Shmatkov, Planta Med. 77, PA17 (2011)

12. J.W. Chen, Z.Q. Zhu, T.X. Hu, D.Y. Zhu, Acta Pharm. Sinica. 23, 667 (2002)

13. S.V. Jovanovic, S. Steenken, Y. Hara, M.G. Simic, J. Chem. Soc., Perkin Trans. 2. 1, 2497 (1996)

14. Y. Chen, P. Deuster, Chem.-Biol. Interac. 182, 7 (2009)

15. A.E. Weidmann, Eur. J. Pharm. 684, 19 (2012)

16. Y.A. Vladimirov, E.V. Proskurnina, E.M. Demin, N.S. Matveeva, O.B. Lubitskiy, A.A. Novikov, D.Y. Izmailov, A.N. Osipov, V.P. Tikhonov, V.E. Kagan, Biochem. (Moscow). 74, 301 (2009)

17. S.G. Dragoev, D.B. Vlahova-Vangelova, D.K. Balev, D.G. Bozhilov, S.Z. Dagnon, Bulg. J. Agric. Sci. 27, 209 (2021)

18. ISO 8589: 1988. Sensory analysis - General guidance for the design of test rooms standard (ISO, Geneva, 1988)

19. J. Jandasek, M. Milerski, M. Lichovnikova, Meat Sci. 96, 88 (2014)

20. J.T. Keeton, B.S. Hafley, S.M. Eddy, C.R. Moser, B.J. McManus, T.P. Leffler, J. AOAC Int. 86, 1193 (2003)

21. AOCS. AOCS Official Method Cd 16b-93 (Am. Oil Chem. Soc., Urbana, IL, 2004)

22. E.G. Bligh, W.J. Dyer, Can. J. Biochem. Physiol. 37, $911(1959)$ 
23. Official methods of analysis of AOAC, Method 922.06 and Method 954.02 (AOAC Int., Rockville, $\mathrm{MD}, 2005)$

24. ISO 12228-1: 2014. Part 1: Animal and vegetable fats and oils. Determination of individual and total sterols contents. Gas chromatographic method (ISO, Geneva, 2014)

25. ISO 9936: 2016. Animal and vegetable fats and oils. Determination of tocopherol and tocotrienol contents by high-performance liquid chromatography (ISO, Geneva, 2016)

26. J.-P. Wolff, Manuel d'analyse des corps gras (Azoulay, Paris, 1968)

27. R.L. Heinrikson, S.C. Meredith, Anal. Biochem. 136, 65 (1984)

28. S.-T. Joo, Korean J. Food Sci. Anim. Res. 38, 823 (2018)

29. ISO 4833: 2003. Microbiology of food and animal feeding stuffs - Horizontal method for the enumeration of microorganisms - Colony-count technique at 30 degrees $C$ (ISO, Geneva, 2003)

30. SAS Statistical Analysis System. SAS Release 9.1 for Windows (SAS Institute Inc., Cary, NC, 2003) 